\title{
Service Failures and How the Perception of Justice Affects the Level of Satisfaction
}

\author{
Submitted 13/12/20, $1^{\text {st }}$ revision 15/01/21, $2^{\text {nd }}$ revision 17/02/21, accepted 20/03/21
}

\author{
Thomas O. Uitz ${ }^{1}$, Eva Jančíková ${ }^{2}$
}

\begin{abstract}
:
Purpose: The market for sports nutrition, vitamins and supplements is rapidly growing especially online. This study focuses on ways to explore service failures and service recovery strategies of students buying online sports nutrition products and supplements during the COIVD-19 crisis. The objective of this study is to contribute to the research in the field of service marketing and develop and understand how a customer evaluate the respond of an online sports nutrition and supplements retailer to a service failure and how the perception of justice affects the level of satisfaction.
\end{abstract}

Design/Methodology/Approach: The goal is met through an extensive literature review and the implementation of practical research. With 155 completed responses from students from eight different universities in CEE and SEE a web-based survey was conducted.

Findings: There a strong evidence of a relationship between a higher effort of the customer and writing a negative online review. Online retailers putting (very) much effort into the situation are not confronted with shoppers writing either a negative or a review in general.

Practical Implications: This research argues for strengthening customer service and a high involvement of customer service managers.

Originality Value: This is a first paper which has analysed the service failures during the Covid-19 crisis.

Keywords: Customer relationship management, service marketing, service failure, service recovery.

JEL codes: $M 1, M 3, O 3$.

Paper type: Research article.

\footnotetext{
${ }^{1}$ Faculty of International Relations, University of Economics in Bratislava, Slovak Republic, e-mail:thomas.uitz@gmx.at

${ }^{2}$ Faculty of International Relations, University of Economics in Bratislava, Slovak Republic, e-mail:eva.jancikova@euba.sk
} 


\section{Introduction}

Wherever the customer meets a business or brand or its products/services, consumer touchpoints are established. Thus, touchpoints are all points of communication that leave the customer with an impression. Employees, the product, or service itself, or all other contact models (both online and offline) can cause these impressions. Those touchpoints are subdivided according to several variables in the literature. On the one side, in terms of time in the consumer relationship - i.e., from the sales transaction to the post-purchase period - they are differentiated from each other. Customer touchpoints, on the other hand, may be split into direct and indirect (influencing the company's power) or one-sided and two-sided customer touchpoints (customer interaction possibilities).

Customer touchpoints are different ways in which customers perceive a product or service before they dispose of it from when they first become aware of it. However, for reasons outside the primary characteristics and features all rivals provide, customers also become loyal to goods and services. It can be substantially differentiated by touchpoints that discuss critical yet ignored issues that customers often care about. Mastering touchpoints is therefore more likely to result in clients selling up to greater quantities and additional sales per buying opportunity. In improving the positioning of the brand and overall perception, every touchpoint plays a role. Important touchpoints that are largely mishandled may send fleeing customers and contribute to negative, unfavourable word of mouth. The objective of this study is to contribute to the research in the field of service marketing and develop and understand how a customer evaluate the respond of an online sports nutrition and supplements retailer to a service failure and how the perception of justice affects the level of satisfaction.

\section{Literature Review}

Social media is described by Mergel and Bretschneider (2016) as an internet-based network that provides consumers with the ability to interact and create content such as text, video and audio. This latest technology modifies the contact conduct of individuals with each other, but also in a business sense (Hanna et al., 2011). The massively increasing number of internet users contributes to a challenge for businesses due to the ability for customers to communicate (respond and complain) independently using any third parties or agencies at any time from all over the world (Cormode and Krishnamurthy, 2008).

The website with the most active users is still Facebook, followed by YouTube, Instagram and WeChat. More than one billion people each have these four social media firms. Consumers have a greater influence on companies than in the past, placing a certain amount of emphasis on the way they connect with customers. To educate themselves, over 81 percent of customers use online feedback to dramatically alter the purchase decision process (Leggatt, 2009). To see whether there is a degree 
of satisfaction or disappointment, Kassim and Ismail (2009) clarify that businesses use social media and other network technologies not only to connect with consumers, but also to market goods and services and determine consumer reactions.

According to Kotler et al. (2019), social media offers service providers the ability to respond more effectively and at a relatively low price compared to conventional tools. Social networking is considered an important component of marketing strategies and offers a deeper understanding of how the retail sector is influenced by social media (Ganesan, 2012). Customers of the new millennium use social media sites as the first source of results. However, this group trusts on friends, social groups, or reviews more than on commercials, advertisements, and promotions (Woodcock et al., 2011). The tone has shifted drastically. In their quest for information for goods and services, consumers rely on eWOM, such as review pages, online posts, rather than using offline sources (Gruen et al., 2006). There are several formats for social media interaction, including images, jokes, feedback, and remarks.

The shared understanding of goods and services is generated by these personal views and experiences. Social networking is a major forum for the propagation of negative eWOM activities. Millions of individuals can distribute negative data within a few hours (Pfeffer et al., 2013). The influence of customers is underlined by Mangold and Smith (2012). They can affect thousands of people's purchasing decisions within a few seconds. To reply to the increasing number of online social media grievances, action plans and strategies need to be planned. Although phones, letters and face-toface contact are still in use to complain, social media provides individuals with a new medium that often anonymously communicates their thoughts and feelings (Tripp and Grégoire, 2011).

There are six main purposes because customers use social media platforms to complain and express their dissatisfaction (Grégoire et al., 2015):

1. Directness

2. Boasting

3. Speak negatively about the company

4. Make others aware of negative experiences with a respective company

5. Take revenge on a company

6. Fuel negativity about the company.

The efficacy of the online service recovery of an organization is determined by the time it takes to resolve the need for recovery of a service (Pang et al., 2014). Companies should plan a method for implementing service recovery plans when problems arise. By responding just in time to a complaint (Chaffey and EllisChadwick, 2012), pre-recovery time can be minimized. More commonly, eWOM is negative than positive in general (Anderson and Salisbury, 2003). Research has shown that effective eWOM contact is favourable for purchasing decisions with 
friends, family, and peers. It is so effective that it is much more successful than conventional marketing instruments.

Andreassen (2000) identifies service recovery as all steps that must be taken by a corporation or agency to resolve a loss. To deter customers from transferring behaviour, an effective service recovery is important (Keaveney, 1995). It is also necessary to develop long-term relationships, enhance customer loyalty and increase profit (McCollough et al., 2000). Research on service management explores the questions about what kinds of activities produce productive recovery of services. Four to five service recovery strategies are defined by most writers. They all differ, but in some areas, they often overlap. Managers need a structure for behaviour for service recovery that they can implement if appropriate (Smith et al., 1999).

Customers' position in service recovery has shifted from passive recipients to cocreators of active value. Recent studies suggest that the effect of consumers on attempts to recover services enhances repurchase intentions (Roggeveen et al., 2011; Guo et al., 2016). From an organizational perspective, service recovery follows three general streams (Smith et al., 1999).

1. Focus on the normative managerial mode (Johnston and Mehra, 2002).

2. Focus on independent sets of service recovery procedures where issues are related to processes, employees and customers are investigated separately (Battaglia et al., 2012) are investigated separately.

3. As an integrated activity where, organisational efforts act synergistically more than independently.

\section{Methodology and Research Methods}

A methodological framework must be developed to provide a transparent service recovery and build a long-term relationship between the company and the customer. The specific research questions are:

- Are the customers satisfied with the actions of the online retailer to recover and overcome the failure in general?

- How big was the own effort and the effort of the company?

- How is the relation to the online retailer after the recovery?

- How do the shoppers react?

Several hypotheses are defined in order to be tested to provide answers about how online retailers can enhance their service.

H1: Online retailer showing no reaction receive more negative reviews on social media than others.

H2: Consumers who are dissatisfied with the service recovery complain more than others on social media afterwards.

H3: Online retailers with a high effort get more positive reviews. 
H4: Customers experiencing a positive service recovery completed the purchase or use the same online retailer more often than customers with a bad experience.

H5: Customers experiencing a positive service recovery continue the intended purchase more often than customers who do not even complain.

Data was obtained from students from the following universities: California Lutheran University MBA Europe Alumni, Czech University of Life Science Prague, Czech Republic, FH Burgenland University of Applied Science, Eisenstadt, Austria, Juraj Dobrila University of Pula and University North Zagreb, Croatia, University of Economics in Bratislava, Slovakia, University of Mostar, Bosnia and Herzegovina and University of Sopron, Hungary. The universities and faculties in the specific countries were selected based on the following criteria:

1. Commitment to research of new areas.

2. Location in Central and Eastern Europe and Southern Europe.

3. The availability of different online retailers within the countries.

To carry out the study, a web-based survey was used through Lime Survey, an online solution for skilled market research. The survey connection was sent out simultaneously to all universities at the end of May 2020 to distribute the questionnaire to the students in June and was available until 31 August 2020. Prior, the web-based questionnaire was pre-tested using a convenience sample of $19 \mathrm{PhD}$ students, lecturers, and online shoppers. The variables were first entered into the assessment program SPSS 23 and descriptively evaluated. For the metric variables, the mean, median, standard deviation, variance, minimum, and maximum were computed. Frequency tables have been developed for nominal and ordinal features.

Since the normal distribution could not be assumed and the homogeneity of variance was not always given (check by Levene test), parameter-free tests were used for the tests. The parameter-free Kruskal-Wallis rank correlation test was initially used to test for differences in variables with several categories; the Mann-Whitney U rank correlation test was also used for further post-hoc testing between two categories and to check for differences in dichotomous variables. The check for differences in nominal or categorical variables was carried out using the chi-square independence test. This means that the "highly significant" results in colloquial language are retained; the values between 0.005 and 0.05 are interpreted, but no longer designated as significant.

\section{Results}

The web-based survey had 287 participants. 155 completed the survey and 122 experienced a service failure while shopping online. 69 were male and 51 female, two participants provided no answer. The following charts will focus on participants who experienced a service failure only. Two third of the respondents were very satisfied 
or satisfied with the provided solution of the service provider whereas eighteen percent stated that they were dissatisfied or very dissatisfied with the solution.

Half of the respondents stated that they put much effort in the process to solve the issue but around thirty nine percent of the retailers showed the same level of effort. Participants who put little effort into the situation were confronted with a third of the service providers who invested much effort. Less than ten percent put very much or almost no effort in the discussion to solve the service failure. In total, the effort of the shoppers was considered higher than the effort of the online retailer. Forty one percent of the respondents felt more dedicated to the online retailer after the service recovery. More than fifty seven percent were considering purchasing again at that retailer whereas thirty five percent wanted to buy somewhere else after experiencing a service failure. Almost sixty percent recommended that retailer although they had an issue but thirty-one of the respondents do not so.

Forty percent of the respondents spread some positive word of mouth after the service recovery whereas twenty five percent spread negative words. In terms of writing an online review twenty seven percent did a positive one but nine percent a negative one. The majority of $63 \%$ did not write any review.

Forty-five respondents wrote an online review. Some of them on more than one channel. More than half expressed themselves on Facebook and Instagram. Together with Amazon it counted for seventy five percent of the channels where they wrote their review. Facebook, Instagram, and Amazon were also the channels where people wrote positive reviews. On the other hand, negative reviews were mainly written on Facebook.

H1: Online retailer showing no reaction receive more negative reviews on social media than others.

The results of the chi square test of association $(2 \times 2)$ show the following results.

There is a strong evidence of a relationship between a high level of effort of customer and spreading negative WOM $\chi^{2}(1, \mathrm{~N}=98)=6.73, \mathrm{p}<.035$. Two cells $(33 \%)$ have expected count less than 5 so the result might be more a tendency than a significant one. From the eleven people who did not receive a reaction from the online retailer, four people wrote a negative online review.

It is not considered as theoretically significant value to be meaningful due to the 0.035 and $33.3 \%$ too low cell occupation. Also, the residuals are rather medium in size, whereas the negative reviews show the most difference. WOM is done faster than sitting down and writing a negative review. The hypothesis is confirmed, online retailer showing no reaction receive significantly more negative reviews on social media than others. 
H2: Consumers who are dissatisfied with the service recovery complain more than others on social media afterwards.

A two-tailed Mann-Whitney U test was conducted to examine whether there were significant differences in between recommendation and the different aspects of a service recovery. The satisfaction values differ significantly between the three groups (positive/negative/no review). The subsequent pairwise tests show which groups differ in each case.

Table 1. H2: Mann-Whitney-U test (all groups)

\begin{tabular}{|c|c|c|c|c|c|c|c|c|c|c|c|c|}
\hline \multicolumn{13}{|c|}{ All three groups } \\
\hline & $\begin{array}{l}\text { Satisfa } \\
\text { ction } \\
\text { with } \\
\text { the } \\
\text { provid } \\
\text { ed } \\
\text { solutio } \\
\text { n }\end{array}$ & $\begin{array}{l}\text { Sat. [a } \\
\text { sincere } \\
\text { apolog } \\
\text { y] }\end{array}$ & $\begin{array}{l}\text { Sat. [a } \\
\text { solutio } \\
\mathrm{n} \text { for } \\
\text { the } \\
\text { proble } \\
\mathrm{m}]\end{array}$ & $\begin{array}{l}\text { Sat. } \\
\text { [courte } \\
\text { sy of } \\
\text { the } \\
\text { service } \\
\text { provid } \\
\text { er] }\end{array}$ & $\begin{array}{l}\text { Sat. } \\
\text { [an } \\
\text { explan } \\
\text { ation } \\
\text { of the } \\
\text { failure } \\
\text { ] }\end{array}$ & $\begin{array}{l}\text { Sat. [a } \\
\text { quick } \\
\text { response } \\
\text { to my } \\
\text { questions } \\
\text { and my } \\
\text { failure] }\end{array}$ & $\begin{array}{l}\text { Sat. } \\
\text { [an } \\
\text { approp } \\
\text { riate } \\
\text { compe } \\
\text { nsation } \\
\text { ] }\end{array}$ & $\begin{array}{l}\text { Sat. } \\
\text { [offeri } \\
\text { ng } \\
\text { profess } \\
\text { ional } \\
\text { support } \\
\text { ] }\end{array}$ & $\begin{array}{l}\text { Sat. } \\
\text { [honestly } \\
\text { effort of } \\
\text { the } \\
\text { company } \\
\text { to solve } \\
\text { my issue] }\end{array}$ & $\begin{array}{l}\text { Sat. [a } \\
\text { follow-up } \\
\text { after the } \\
\text { problem } \\
\text { was } \\
\text { solved] }\end{array}$ & $\begin{array}{l}\text { Sat. [a } \\
\text { good and } \\
\text { fast } \\
\text { availabilit } \\
y \text { of the } \\
\text { company] }\end{array}$ & $\begin{array}{l}\text { Sat. } \\
\text { [personal } \\
\text { contact by } \\
\text { telephone } \\
\text { ] }\end{array}$ \\
\hline $\begin{array}{l}\text { Pearso } \\
\text { n Chi- } \\
\text { Square }\end{array}$ & 41.778 & 29.115 & 32.285 & 20.932 & 18.758 & 22.444 & 20.417 & 15.658 & 17.929 & 16.129 & 23.718 & 7.178 \\
\hline $\mathrm{d}$ & 2 & 2 & 2 & 2 & 2 & 2 & 2 & 2 & 2 & 2 & 2 & 2 \\
\hline $\begin{array}{l}\text { Asymp } \\
\text { totic } \\
\text { Signifi } \\
\text { cance } \\
\text { (2- } \\
\text { sided) }\end{array}$ & .000 & .000 & .000 & .000 & .000 & .000 & .000 & .000 & .000 & .000 & .000 & .028 \\
\hline
\end{tabular}

Source: Own study.

All individual satisfaction values are significantly different between the positive and negative reviews.

Table 2. H2: Mann-Whitney-U test (positive/negative reviews)

\begin{tabular}{|c|c|c|c|c|c|c|c|c|c|c|c|c|}
\hline \multicolumn{13}{|c|}{ positive/ negative reviews } \\
\hline & $\begin{array}{l}\text { Satisfaction } \\
\text { with the } \\
\text { provided } \\
\text { solution }\end{array}$ & $\begin{array}{l}\text { Sat. [a } \\
\text { sincere } \\
\text { apolog } \\
\text { y] }\end{array}$ & $\begin{array}{l}\text { Sat. [a } \\
\text { solutio } \\
\mathrm{n} \text { for } \\
\text { the } \\
\text { proble } \\
\mathrm{m}]\end{array}$ & $\begin{array}{l}\text { Sat. } \\
\text { [courte } \\
\text { sy of } \\
\text { the } \\
\text { service } \\
\text { provide } \\
\text { r] }\end{array}$ & $\begin{array}{l}\text { Sat. [an } \\
\text { explanati } \\
\text { on of the } \\
\text { failure] }\end{array}$ & $\begin{array}{l}\text { Sat. [a } \\
\text { quick } \\
\text { respons } \\
\text { e to my } \\
\text { questio } \\
\text { ns and } \\
\text { my } \\
\text { failure] }\end{array}$ & $\begin{array}{l}\text { Sat. [an } \\
\text { appropriate } \\
\text { compensati } \\
\text { on] }\end{array}$ & $\begin{array}{l}\text { Sat. } \\
\text { [offering } \\
\text { professio } \\
\text { nal } \\
\text { support] }\end{array}$ & $\begin{array}{l}\text { Sat. } \\
\text { [honest } \\
\text { ly } \\
\text { effort } \\
\text { of the } \\
\text { compa } \\
\text { ny to } \\
\text { solve } \\
\text { my } \\
\text { issue] }\end{array}$ & $\begin{array}{l}\text { Sat. [a } \\
\text { follow } \\
\text {-up } \\
\text { after } \\
\text { the } \\
\text { proble } \\
\text { m was } \\
\text { solved } \\
\text { ] }\end{array}$ & $\begin{array}{l}\text { Sat. [a } \\
\text { good and } \\
\text { fast } \\
\text { availabili } \\
\text { ty of the } \\
\text { company } \\
\text { ] }\end{array}$ & $\begin{array}{l}\text { Sat. } \\
\text { [persona } \\
1 \text { contact } \\
\text { by } \\
\text { telephon } \\
\text { e] }\end{array}$ \\
\hline $\begin{array}{l}\text { Mann- } \\
\text { Whitney- } \\
\text { U } \\
\end{array}$ & 1.000 & 12.500 & 5.000 & 18.000 & 35.500 & 31.000 & 11.500 & 25.000 & 28.000 & 14.500 & 23.500 & 19.500 \\
\hline $\begin{array}{l}\text { Wilcoxon } \\
- \text { W }\end{array}$ & 526.000 & $\begin{array}{l}573.50 \\
0\end{array}$ & $\begin{array}{l}566.00 \\
0\end{array}$ & $\begin{array}{l}514.00 \\
0\end{array}$ & 596.500 & $\begin{array}{l}592.00 \\
0\end{array}$ & 539.500 & 460.000 & $\begin{array}{l}589.00 \\
0 \\
\end{array}$ & $\begin{array}{l}257.50 \\
0 \\
\end{array}$ & 584.500 & 272.00 \\
\hline $\mathrm{Z}$ & -5.051 & -4.338 & -4.875 & -4.875 & -3.041 & -3.289 & -3.998 & -3.261 & -3.365 & -3.040 & -3.716 & -2.687 \\
\hline $\begin{array}{l}\text { Asymptot } \\
\text { ic } \\
\text { Significan } \\
\text { ce (2- } \\
\text { sided) }\end{array}$ & .000 & .000 & .000 & .000 & .002 & .001 & .000 & .001 & .001 & .002 & .000 & .007 \\
\hline
\end{tabular}

Source: Own study. 
Apart from offering professional support and personal contact, there are significant differences in the other satisfaction values between the positive and no reviews.

Table 3. H2: Mann-Whitney-U test (positive/no review)

\begin{tabular}{|c|c|c|c|c|c|c|c|c|c|c|c|c|}
\hline \multicolumn{13}{|c|}{ positive/ no review } \\
\hline & $\begin{array}{l}\text { Satisfac } \\
\text { tion } \\
\text { with the } \\
\text { provide } \\
\text { d } \\
\text { solution }\end{array}$ & $\begin{array}{l}\text { Sat. } \\
{[a} \\
\text { sincer } \\
\text { e } \\
\text { apolo } \\
\text { gy] }\end{array}$ & $\begin{array}{l}\text { Sat. [a } \\
\text { soluti } \\
\text { on for } \\
\text { the } \\
\text { probl } \\
\text { em] }\end{array}$ & $\begin{array}{l}\text { Sat. } \\
\text { [court } \\
\text { esy of } \\
\text { the } \\
\text { servic } \\
\text { e } \\
\text { provi } \\
\text { der] }\end{array}$ & $\begin{array}{l}\text { Sat. [an } \\
\text { explana } \\
\text { tion of } \\
\text { the } \\
\text { failure] }\end{array}$ & $\begin{array}{l}\text { Sat. [a } \\
\text { quick } \\
\text { respo } \\
\text { nse to } \\
\text { my } \\
\text { questi } \\
\text { ons } \\
\text { and } \\
\text { my } \\
\text { failure } \\
\text { ] }\end{array}$ & $\begin{array}{l}\text { Sat. [an } \\
\text { appropria } \\
\text { te } \\
\text { compensa } \\
\text { tion] }\end{array}$ & $\begin{array}{l}\text { Sat. } \\
\text { [offerin } \\
\mathrm{g} \\
\text { professi } \\
\text { onal } \\
\text { support] }\end{array}$ & $\begin{array}{l}\text { Sat. } \\
\text { [hone } \\
\text { stly } \\
\text { effort } \\
\text { of the } \\
\text { comp } \\
\text { any to } \\
\text { solve } \\
\text { my } \\
\text { issue] }\end{array}$ & $\begin{array}{l}\text { Sat. } \\
\text { [a } \\
\text { follo } \\
\text { w-up } \\
\text { after } \\
\text { the } \\
\text { probl } \\
\text { em } \\
\text { was } \\
\text { solve } \\
\text { d] }\end{array}$ & $\begin{array}{l}\text { Sat. [a } \\
\text { good } \\
\text { and fast } \\
\text { availab } \\
\text { ility of } \\
\text { the } \\
\text { compa } \\
\text { ny] }\end{array}$ & $\begin{array}{l}\text { Sat. } \\
\text { [perso } \\
\text { nal } \\
\text { contact } \\
\text { by } \\
\text { teleph } \\
\text { one] }\end{array}$ \\
\hline $\begin{array}{l}\text { Mann- } \\
\text { Whitney } \\
-U\end{array}$ & 372.000 & $\begin{array}{l}354.0 \\
00\end{array}$ & $\begin{array}{l}385.5 \\
00\end{array}$ & $\begin{array}{l}445.5 \\
00\end{array}$ & $\begin{array}{l}385.00 \\
0\end{array}$ & $\begin{array}{l}429.5 \\
00\end{array}$ & 495.500 & 456.500 & $\begin{array}{l}502.0 \\
00\end{array}$ & $\begin{array}{l}158.5 \\
00\end{array}$ & $\begin{array}{l}375.00 \\
0\end{array}$ & $\begin{array}{l}271.00 \\
0\end{array}$ \\
\hline $\begin{array}{l}\text { Wilcoxo } \\
n-W\end{array}$ & 933.000 & $\begin{array}{l}915.0 \\
00\end{array}$ & $\begin{array}{l}946.5 \\
00\end{array}$ & $\begin{array}{l}941.5 \\
00 \\
\end{array}$ & $\begin{array}{l}946.00 \\
0 \\
\end{array}$ & $\begin{array}{l}990.5 \\
00\end{array}$ & 1023.500 & 891.500 & $\begin{array}{l}1063 . \\
000\end{array}$ & $\begin{array}{l}411.5 \\
00\end{array}$ & $\begin{array}{l}936.00 \\
0 \\
\end{array}$ & $\begin{array}{l}524.00 \\
0\end{array}$ \\
\hline $\mathrm{Z}$ & -4.978 & $\begin{array}{l}- \\
4.718\end{array}$ & $\begin{array}{l} \\
4.741\end{array}$ & 3.512 & -3.777 & -4.129 & -3.393 & -2.190 & -3.064 & 3.453 & -4.317 & -1.627 \\
\hline $\begin{array}{l}\text { Asympt } \\
\text { otic } \\
\text { Signific } \\
\text { ance (2- } \\
\text { sided) } \\
\end{array}$ & .000 & .000 & .000 & .000 & .000 & .000 & .001 & .029 & .002 & .001 & .000 & .104 \\
\hline
\end{tabular}

Source: Own study.

In contrast, significant differences between the negative and no reviews can only be found in the appropriate compensation.

Table 4. H2: Mann-Whitney-U test (negative/no review)

\begin{tabular}{|l|l|l|l|l|l|l|l|l|l|l|l|l|}
\hline \multicolumn{10}{|c|}{ negative /no review } \\
\hline & $\begin{array}{l}\text { Satisfac } \\
\text { tion } \\
\text { with the } \\
\text { provide } \\
\mathrm{d} \\
\text { solution }\end{array}$ \\
\end{tabular}

Source: Own study.

The cell occupancy is too low and the events that are significant in themselves should not be considered valid. Nevertheless, the individual differences show up quite well and be a tendency. 
Figure 1. H2: Satisfaction with the provided solution

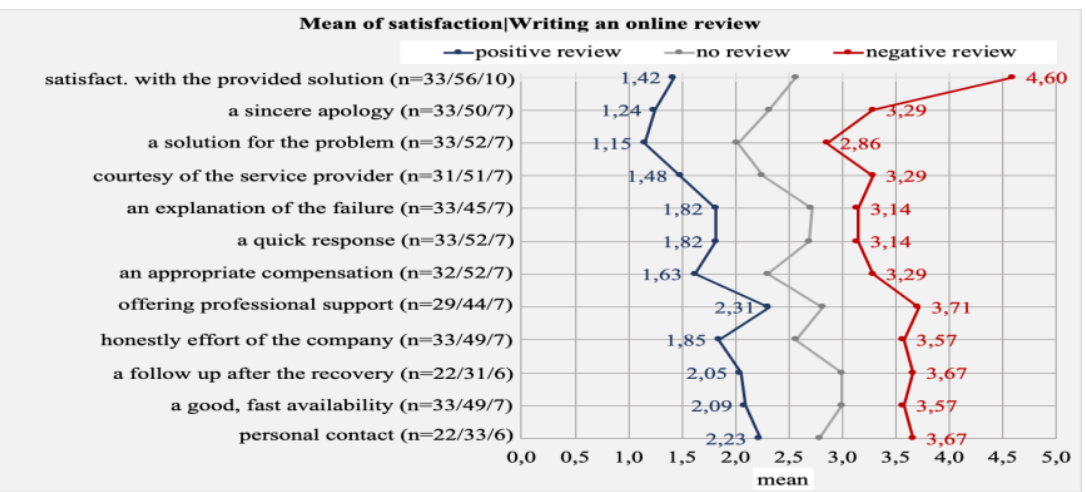

Source: Own study.

The hypothesis is confirmed, consumers who are dissatisfied with the service recovery complain significantly more than others on social media.

H3: Online retailers with a high effort get more positive reviews.

The results of the chi square test of association $(2 \times 2)$ show the following results. There is a strong evidence of a relationship between a higher effort of the customer and writing a negative online review $\chi^{2}(2, \mathrm{~N}=120)=27.96, \mathrm{p}<.000$. Like the situation with spreading WOM the higher the effort of the customer is the higher is their willingness to share their negative experience, either in writing or oral. Online retailers putting (very) much effort into the situation are not confronted with shoppers writing either a negative or a review in general. On the contrary, $40 \%$ of the shoppers wrote a negative review when the online retailers did not put any effort in the service recovery process.

The hypothesis is confirmed, online retailers with a high effort get significantly more positive reviews.

H4: Customers experiencing a positive service recovery completed the purchase or use the same online retailer more often than customers with a bad experience.

The results of the chi square test of association $(2 \times 2)$ show that there is a strong evidence of a relationship between a very dissatisfied solution and stop buying/buy somewhere else $\chi^{2}(2, \mathrm{~N}=90)=52.61, \mathrm{p}<.000$. Two cells $(33 \%)$ have expected count less than 5 so the result might be more a tendency than a significant one. People who are very dissatisfied significantly buy somewhere else or buy nothing.

Here, the reactions are summarised in two categories. The largest group is those who continued to buy. Those were added who bought from the same retailer later or directly in the store. The second group is made up of those who cancelled their 
purchase or went to another retailer. People who are very dissatisfied continue shopping at another retailer significantly more often or do not buy at all. The cell occupation is borderline, but due to the highly significant $\mathrm{p}$-value it is included.

The hypothesis is confirmed, customers experiencing a positive service recovery completed the purchase or use the same online retailer significantly more often than customers with a bad experience.

H5: Customers experiencing a positive service recovery continue the intended purchase more often than customers who do not even complain.

The results of the chi square test of association (2x2) show that there is a strong evidence of a relationship between a customer complaint and a completed purchase $\chi^{2}(1, N=110)=20.21, p<.000$. Shoppers who complained, significantly continuing buying at that retailer than people wo did not complain.

Here a new group variable yes/no complained was created, which consists of those who have not complained and the others. The variable "happened "is now also combined for both groups. This clearly confirms the hypothesis. People who have complained continue shopping at this retailer significantly more than those who have not complained.

\section{Discussion}

A survey has found that $96 \%$ of Millennials and Generation Z's are worried about the pandemic and its economic consequences. This concern causes them more radically to change their actions than other generations, including reducing spending, stocking up on goods, and spending less on experiences. While coronavirus and its effects on the economy remain a concern, older generations are slightly less concerned than younger generations and have less impact on their shopping habits. For instance, compared to almost half of Millennials, 24 percent of Boomers and 34 percent of Gen $\mathrm{X}$ said they were letting current events influence what things they buy (Coronavirus crisis' consumer impact-new data on purchase decisions and behaviors, 2020).

According to Czepiel (1990), organizations focus on the service itself in their efforts to continually improve their service delivery, but service meetings and social exchanges are identified as the key factors in the literature. Scholars have suggested that efforts to meet customer service expectations should focus on structural opportunities for sociability and greater interaction between consumers and service providers, leading to more desirable procedural and interactive justice that leads to more happy customers (Tax and Brown, 1998).

The findings of this study are consistent with previous findings that compensation has a positive effect on WOM and the intent to repurchase (Smith et al., 1999). Bitner (1990) noted that providers of services that demonstrate that a service failure is 
uncontrollable may receive a positive response from customers. In this report, shoppers consider the problem's interpretation as not that significant and no significant findings have been identified.

An online survey provides several advantages, such as lower costs, better pacing, and less content. The data could, on the other hand, be compromised. Self-selection is a significant drawback in performing a web-based survey, according to Blom et al. (2015), because the respondents are not randomly chosen, which could lead to a bias error. Other barriers may be present, such as insufficient data, high non-response rates and internet accessibility. Wright (2005) noted that, as is the case in this report, online surveys can provide access to a specific population that primarily gathers online. With the absence of a human interviewer, respondents appear to be franker with their responses (Chang and Krosnick, 2010).

Online survey response rates are lower than those for telephone or mail surveys. As the degree of motivation declines, participants are more likely to be quite halfway away. However, the interface can also influence the participants' outcomes and behaviour (Tourangeau et al., 2013). But also, the system used to complete the survey can affect the rate of drop-out. Smartphone and tablet tend to provide shorter answers and are less likely to complete the survey due to ta smaller keyboard size (Lambert $\&$ Miller, 2014). This study focuses on CEE/SEE students, so the findings cannot be applicable to the population. In addition, in that case, the overall effect of COVID-19 is quite ambiguous about online shopping behaviour, participant availability, online retailer issues.

\section{Conclusions}

Online retailers showing no response, no participation, and no attempt to solve the problem of the customer are faced with shoppers who spread negative WOM are at risk of losing credibility. This seems to be very important, and it is crucial for online retailers to have an atmosphere where disgruntled consumers can communicate their dissatisfaction with the service provider, but not with the worldwide network.

The greater the customer's effort, either in writing or verbally, the greater their ability to share their adverse experiences. Online retailers are not faced with shoppers writing either a negative or an overall review when they put (very much effort into the situation. In comparison, while online retailers did not put any effort into the service recovery process, 40 percent of shoppers wrote a negative review. On Facebook and Instagram, more than half shared themselves. Together with Amazon it counted for seventy five percent of the channels where they wrote their review.

The platforms where people wrote good feedback were Facebook, Instagram, and Amazon as well. Negative reviews were mostly posted on Facebook, on the other hand. It is therefore necessary to manage social manager channels because shoppers rely more on eWOM than on offline sources, such as review sites. WOM is done 
more easily than sitting down and writing an unfavourable review. Yet both acts can have significant implications for the online retailer which can lead to less loyalty and the purpose of repurchasing.

\section{References:}

Anderson, E.W., Salisbury, L.C. 2003. The Formation of Market-Level Expectations and Its Covariates. Journal of Consumer Research, 30(1), 115-124.

Andreassen, T.W. 2000. Antecedents to satisfaction with service recovery. European Journal of Marketing, 34(1/2), 156-175.

Bitner, M.J. 1990. Evaluating Service Encounters: The Effects of Physical Surroundings and Employee Responses. Journal of Marketing, 54(2), 69.

Bitner, M.J., Booms, B.H., Tetreault, M.S. 1990. The Service Encounter: Diagnosing Favorable and Unfavorable Incidents. Journal of Marketing, 54(1), 71.

Blom, A.G., Gathmann, C., Krieger, U. 2015. Setting Up an Online Panel Representative of the General Population. Field Methods, 27(4), 391-408.

Chaffey, D., Ellis-Chadwick, F. 2012. Digital marketing: Strategy, implementation, and practice. Harlow: Pearson.

Chang, L., Krosnick, J.A. 2010. Comparing Oral Interviewing with Self-Administered Computerized Questionnaires. An Experiment. Public Opinion Quarterly, 74(1), 154-167.

Cormode, G., Krishnamurthy, B. 2008. Key differences between Web 1.0 and Web 2.0. First Monday.

Coronavirus crisis' consumer impact-new data on purchase decisions and behaviors. 2020. Retrieved from https://www.agilitypr.com/pr-news/public-relations/coronaviruscrisis-consumer-impact-new-data-on-purchase-decisions-and-behaviors/

Czepiel, J.A. 1990. Service encounters and service relationships: Implications for research. Journal of Business Research, 20(1), 13-21.

Ganesan, S. 2012. From the editor - Journal of Retailing in the global marketplace. Journal of Retailing, 88(2), 189-190.

Grégoire, Y., Salle, A., Tripp, T.M. 2015. Managing social media crises with your customers: The good, the bad, and the ugly. Business Horizons, 58(2), 173-182.

Gruen, T.W., Osmonbekov, T., Czaplewski, A.J. 2006. EWOM: The impact of customer-tocustomer online know-how exchange on customer value and loyalty. Journal of Business Research, 59(4), 449-456.

Guo, L., Lotz, S.L., Tang, C., Gruen, T.W. 2015. The Role of Perceived Control in Customer Value Cocreation and Service Recovery Evaluation. Journal of Service Research, 19(1), 39-56.

Hanna, R., Rohm, A., Crittenden, V.L. 2011. We are all connected: The power of the social media ecosystem. Business Horizons, 54(3), 265-273.

Johnston, R., Mehra, S. 2002. Best-practice complaint management. Academy of Management Perspectives, 16(4), 145-154.

Kassim, N.M., Ismail, S. 2009. Investigating the complex drivers of loyalty in e-commerce settings. Measuring Business Excellence, 13(1), 56-71.

Keaveney, S.M. 1995. Customer Switching Behavior in Service Industries: An Exploratory Study. Journal of Marketing, 59(2), 71.

Kotler, P., Manceau, D., Keller, K.L., Hemonnet-Goujot, A. 2019. Marketing management. Montreuil: Pearson. 
Lambert, A.D., Miller, A.L. 2014. Living with Smartphones: Does Completion Device Affect Survey Responses? Research in Higher Education, 56(2), 166-177.

Leggatt, H. 2009. What reaction do consumers have to negative reviews? Retrieved from http://www.bizreport.com/2009/02/what_reaction_do_consumers_have_to_negativ e reviews.html.

Mangold, W.G., Smith, K.T. 2012. Selling to Millennials with online reviews. Business Horizons, 55(2), 141-153.

McCollough, M.A., Berry, L.L., Yadav, M.S. 2000. An Empirical Investigation of Customer Satisfaction after Service Failure and Recovery. Journal of Service Research, 3(2), 121-137.

Mergel, I., Bretschneider, S.I. 2013. A Three-Stage Adoption Process for Social Media Use in Government. Public Administration Review, 73(3), 390-400.

Pang, A., Hassan, N.B., Chong, A.C. 2014. Negotiating crisis in the social media environment. Corporate Communications: An International Journal, 19(1), 96-118.

Pfeffer, J., Zorbach, T., Carley, K.M. 2013. Understanding online firestorms: Negative word-of-mouth dynamics in social media networks. Journal of Marketing Communications, 20(1-2), 117-128.

Roggeveen, A.L., Tsiros, M., Grewal, D. 2011. Understanding the co-creation effect: When does collaborating with customers provide a lift to service recovery? Journal of the Academy of Marketing Science, 40(6), 771-790.

Smith, A.K., Bolten, R.N., Wagner, J. 1999. A model of customer satisfaction with service encounters involving failure and recovery. Journal of Marketing Research, 36(3), 356-372.

Tax, S.S., Brown, S.W. 1998. Recovering and learning from service failure. MIT Sloan Management Review, 40(1), 75-88.

Tourangeau, R., Conrad, F.G., Couper, M. 2013. The science of web surveys. Oxford: Oxford University Press.

Tripp, T.M., Grégoire, Y. 2011. When unhappy customers strike back on the Internet. MIT Sloan Management Review, 52(3), 37-44.

Turban, E. 2015. Electronic commerce: A managerial and social networks perspective. Cham: Springer.

Woodcock, N., Green, A., Starkey, M. 2011. Social CRM as a business strategy. Journal of Database Marketing \& Customer Strategy Management, 18(1), 50-64.

Wright, K.B. 2005. Researching Internet-based populations: Advantages and disadvantages of online survey research, online questionnaire authoring software packages, and web survey services. Journal of Computer-Mediated Communication. 